Polymer Journal, Vol. 38, No. 8, pp. 844-851 (2006)

(C) 2006 The Society of Polymer Science, Japan

\title{
Preparation of Antibacterial Polymer-grafted Nano-sized Silica and Surface Properties of Silicone Rubber Filled with the Silica
}

\author{
Risako Yamashita, ${ }^{1}$ Yoko TAKeUChI, ${ }^{1}$ Hirofumi KIKUCHI,${ }^{3}$ Kumi SHIRAI, ${ }^{1}$ \\ Takeshi YAMAUCHI, ${ }^{2,4}$ and Norio TSUBOKAWA ${ }^{1,3,4, \dagger}$ \\ ${ }^{1}$ Department of Material Science and Technology, Faculty of Engineering, Niigata University, \\ 8050, Ikarashi 2-no-cho, Niigata 950-218, Japan \\ ${ }^{2}$ Graduate School of Science and Technology, Niigata University, 8050, Ikarashi 2-no-cho, Niigata 950-2181, Japan \\ ${ }^{3}$ Niigata University Venture Business Laboratory, 8050, Ikarashi 2-no-cho, Niigata 950-2181, Japan \\ ${ }^{4}$ Center for Transdisciplinary Research, Niigata University, 8050, Ikarashi 2-nocho, Niigata 950-2181, Japan
}

(Received January 26, 2006; Accepted May 2, 2006; Published July 14, 2006)

\begin{abstract}
Antibacterial polymer was grafted onto nano-sized silica surface and the surface properties of silicone rubber filled with the silica were investigated. The grafting of antibacterial polymer was carried out by two-step reactions as follows. Poly ( $p$-styrene sodium sulfate) (poly $\left(\mathrm{St}_{-} \mathrm{SO}_{3}{ }^{-} \mathrm{Na}^{+}\right)$) was successfully grafted onto nano-sized silica surface by the radical polymerization of $\mathrm{St}_{-} \mathrm{SO}_{3}{ }^{-} \mathrm{Na}^{+}$initiated by the system consisting of trichloroacetyl groups on the silica surface and $\mathrm{Mo}(\mathrm{CO})_{6}$ : trichloroacetyl groups were introduced onto the silica surface by the reaction of amino groups with trichloroacetyl isocyanate. The percentage of poly $\left(\mathrm{St}_{-} \mathrm{SO}_{3}{ }^{-} \mathrm{Na}^{+}\right)$grafting increased with progress of the polymerization and reached about $30 \%$. The poly $\left(\mathrm{St}_{-} \mathrm{SO}_{3}{ }^{-} \mathrm{Na}^{+}\right)$-grafted silica was treated with tributyltetradecylphosphonium chloride $\left(\mathrm{Bu}_{3} \mathrm{RP}^{+} \mathrm{Cl}^{-}\right)$to convert the $\mathrm{SO}_{3}{ }^{-} \mathrm{Na}^{+}$groups to alkyl phosphonium salt, $\mathrm{SO}_{3}{ }^{-} \mathrm{P}^{+} \mathrm{Bu}_{3} \mathrm{R}$, groups. The grafting of poly $\left(\mathrm{St}_{-} \mathrm{SO}_{3}{ }^{-} \mathrm{P}^{+} \mathrm{Bu}\right.$ R $\mathrm{R}$ ) onto the silica surface was confirmed by IR spectra. The poly $\left(\mathrm{St}_{-} \mathrm{SO}_{3}{ }^{-} \mathrm{P}^{+} \mathrm{Bu}_{3} \mathrm{R}\right)-$ grafted silica gave a stable dispersion in DMSO and poly(dimethylsiloxane). It was found that silicone rubber filled with the poly $\left(\mathrm{St}_{-} \mathrm{SO}_{3}{ }^{-} \mathrm{P}^{+} \mathrm{Bu}_{3} \mathrm{R}\right)$-grafted silica shows extremely strong antibacterial activity. The silicone rubber surface has an ability to inhibit the reproduction of a Staphylococcus aureus and an Escherichia coli. [doi:10.1295/polymj.PJ2005225]

KEY WORDS Nano-sized Silica / Surface Grafting of Polymer / Polymeric Alkyl Phosphonium Salt / Antibacterial Surface / Silicone Rubber / Composite /
\end{abstract}

Many researchers have extensively studied the chemical and physical modifications of nano-sized particle surfaces. The chemical modification of surfaces is permanent, but physical modification is temporary. Among the permanent chemical modifications, the surface grafting of polymers, namely, chemical binding of polymers onto nano-sized particles, such as silica and carbon black, interests us for use in designing new functional inorganic/organic hybrid materials, which have the excellent properties both of inorganic materials, such as heat-resistance and chemical-resistance, and of grafted polymers, such as photosensitivity, curing ability, bioactivity, biocompatibility, and pharmacological activities. ${ }^{1-3}$ For example, we have reported that biocompatible polymer-grafted nano-sized silica surface shows antithrombus characteristic. ${ }^{4}$

In our previous work, we have reported the radical grafting of various vinyl monomers onto nano-sized silica ${ }^{5}$ and carbon black ${ }^{6}$ initiated by surface radicals formed by thermal decomposition of azo groups previously introduced onto the surface. We have also re- ported that the system consisting of $\mathrm{Mo}(\mathrm{CO})_{6}$ and surface trichloroacetyl groups on the nano-sized materials, such as silica ${ }^{7}$ and vapor grown carbon fiber (VGCF), ${ }^{8}$ has an ability to initiate the radical polymerization of various vinyl monomers to give the corresponding polymer-grafted silica and VGCF. We pointed out that the effective radical grafting was achieved in the initiating system consisting of trichloroacetyl groups and $\mathrm{Mo}(\mathrm{CO})_{6}$, and percentage of grafting exceeded $200 \%$, because no fragment radicals are formed. ${ }^{7,8}$

It was reported that the grafting of polymers from particle surface was successfully achieved by atom transfer polymerization initiated by the system consisting of surface groups and transition metal complex. ${ }^{9,10}$ The grafting of polymers onto colloidal silica surface was also reported by Yoshinaga et al. ${ }^{11-13}$

On the other hand, various kinds of antibacterial polymer polymers were reported. ${ }^{14-17}$ For example, alkyl phosphonium polymer shows extremely strong antibacterial nature to Escherichia coli and Staphylococcus aureus. It is expected that when antibacterial

†To whom correspondence should be addressed (Tel\&Fax: +81-25-262-6779, E-mail: ntsuboka@eng.niigata-u.ac.jp). 
polymer-grafted silica was compounded with various polymers, the silica acts as a reinforcing filler and antibacterial polymer chain grafted onto silica surface can give antibacterial nature as schematically shown in Figure 1. The composite has potential use as sanitary goods, toilet seats, and medical materials.

In this paper, the radical grafting of $\operatorname{poly}(p$-styrene sodium sulfate) onto nanosized silica surface (Scheme 1) and conversion of the grafted chain to antibacterial polymer, polymeric alkyl phosphonium salt, were investigated (Scheme 2). In addition, the antibacterial nature of composite prepared from silicone rubber and the polymeric alkyl phosphonium salt-grafted silica will be discussed.

\section{EXPERIMENTAL}

\section{Materials}

Nano-sized silica used was obtained from Nippon

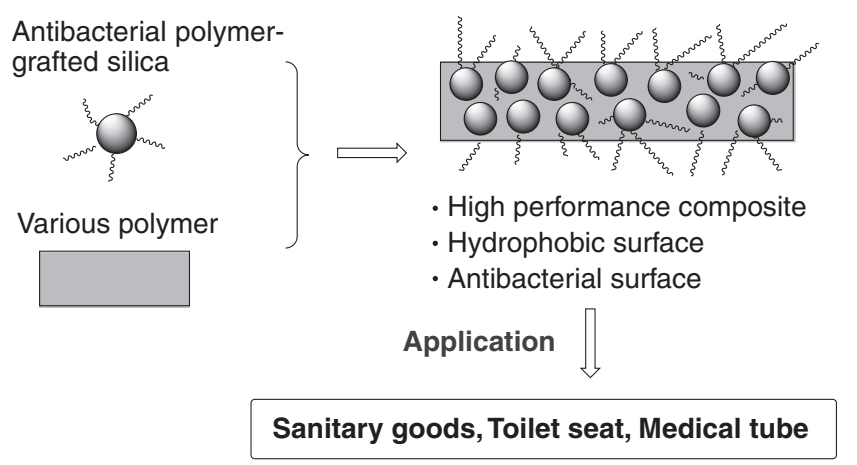

Figure 1. Surface properties of composite prepared from antibacterial polymer-grafted nano-sized silica.
Aerosil Co., Ltd. Japan. The specific surface area, average particle size, and silanol group content are $200 \mathrm{~m}^{2} / \mathrm{g}, 12 \mathrm{~nm}$, and $1.37 \mathrm{mmol} / \mathrm{g}$, respectively. The silica was dried in vacuo at $110^{\circ} \mathrm{C}$ for $48 \mathrm{~h}$ before use. Silicone rubber (X-35-302; two-component type) was obtained from Shin-Etsu Chemical Co., Ltd. Japan.

$p$-Styrene sodium sulfate $\left(\mathrm{St}_{-} \mathrm{SO}_{3}{ }^{-} \mathrm{Na}^{+}\right)$was obtained from Wako Pure Chemical Co., Ltd. Japan and used without further purification. 4,4'-Azobis(4cyanopentanoic acid) (ACPA) obtained from Wako Pure Chemical Co., Ltd. Japan was recrystallized from methanol and dried in vacuo at room temperature. Tolylene 2,4-diisocyanate (TDI) and dimethyl sulfoxide (DMSO) were distilled before use. $\gamma$-Aminopropyltriethoxysilane ( $\gamma$-APS), trichloroacetyl isocyanate, and molybdenum hexacarbonyl $\left(\mathrm{Mo}(\mathrm{CO})_{6}\right)$, obtained from Kanto Chemical Co., Ltd. Japan were used without further purification.

Tributyltetradecylphosphonium chloride $\left(\mathrm{Bu}_{3} \mathrm{RP}^{+}\right.$ $\mathrm{Cl}^{-}$) was synthesized by the reaction of tri- $n$-butylphosphine $\left(\mathrm{Bu}_{3} \mathrm{RP}\right)$ with 1-chlorotetradecane $(\mathrm{R}-\mathrm{Cl})$ according to the method of literature. ${ }^{17}$

\section{Introduction of Azo Groups and Trichloroacetyl Groups onto Nano-sized Silica Surface}

The introduction of azo groups onto nano-sized silica surface was achieved by the reaction of $4,4^{\prime}$-azobis(4-cyanopentanoic acid) with isocyanate groups on the surface, which were introduced by the treatment of the silica having amino groups. The introduction of amino groups onto the silica surface was achieved by the treatment with $\gamma$-aminopropyltriethoxysilane. ${ }^{7}$ The content of azo groups introduced onto

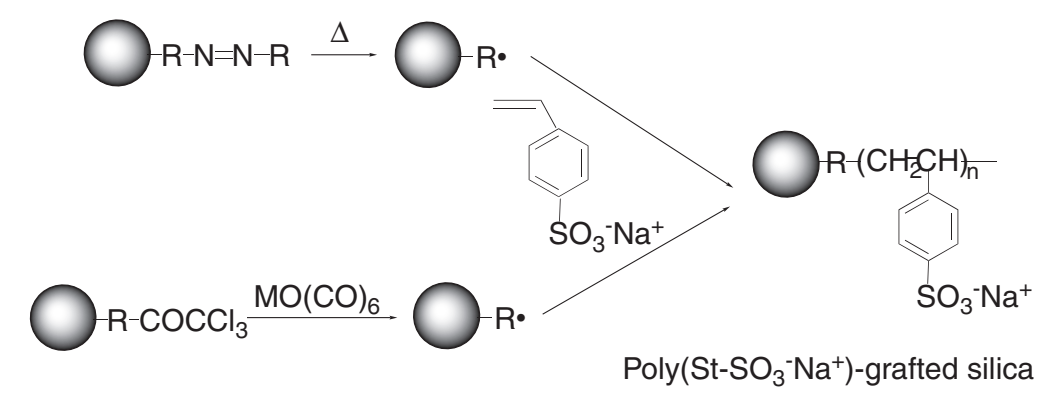

Scheme 1.

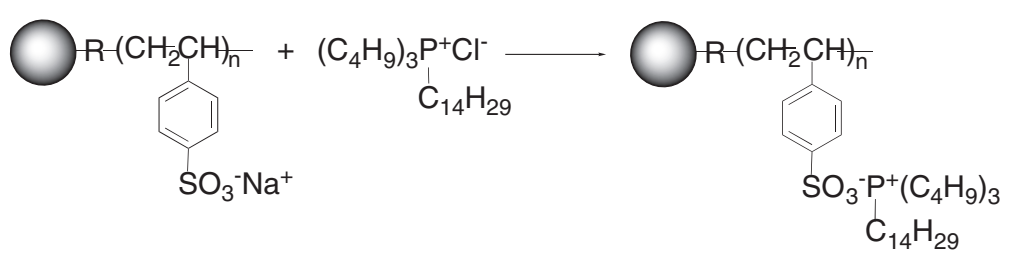

Poly $\left(\mathrm{St}-\mathrm{SO}_{3}{ }^{-} \mathrm{Na}^{+}\right)$-grafted silica

Poly $\left(\mathrm{St}_{-} \mathrm{SO}_{3}{ }^{-}{ }^{+}{ }^{+} \mathrm{Bu}_{3} \mathrm{R}\right)$-grafted silica

Scheme 2. 
silica surface, which was determined from the exothermic peak area, was $0.27 \mathrm{mmol} / \mathrm{g}$. The treated silica was abbreviated as Silica-azo.

The introduction of trichloroacetyl groups onto nano-sized silica was achieved by the reaction of trichloroacetyl isocyanate with amino groups on the silica surface. ${ }^{7}$ The content of trichloroacetyl groups introduced onto silica surface, which was determined from the unreacted amino groups, was 0.23 $\mathrm{mmol} / \mathrm{g}$. The treated silica was abbreviated as Silica-COCCl ${ }_{3}$.

Graft Polymerization of $\mathrm{St}_{-} \mathrm{SO}_{3}{ }^{-} \mathrm{Na}^{+}$Initiated by Azo Groups Introduced onto Nano-sized Silica Surface

The radical graft polymerization of $\mathrm{St}_{-} \mathrm{SO}_{3}{ }^{-} \mathrm{Na}^{+}$initiated by azo groups introduced onto silica surface was carried out in a sealed tube under high vacuum. A typical example was as follows. Into a polymerization tube, $0.20 \mathrm{~g}$ of Silica-azo, $0.50 \mathrm{~g}$ of St- $\mathrm{SO}_{3}{ }^{-} \mathrm{Na}^{+}$, and $10.0 \mathrm{~mL}$ of DMSO as a solvent and a stirrer bar were charged. The mixture was frozen in a liquid nitrogen bath, degassed with a vacuum pump, and then thawed. After this operation was repeated three times, the tube was sealed under high vacuum. The sealed tube was heated at $70^{\circ} \mathrm{C}$ with stirring. After the graft polymerization, the content of the tube was poured into a large excess of methanol. The precipitate thus obtained was filtered and dried in vacuo. Conversion was calculated by the following equation:

$$
\text { Conversion }(\%)=(A-B) / C \times 100 .
$$

where $A$ is weight of product, $B$ is weight of silica charged, and $C$ is weight of monomer charged.

Graft Polymerization of $\mathrm{St}_{-} \mathrm{SO}_{3}{ }^{-} \mathrm{Na}^{+}$Initiated by the System Consisting of Trichloroacetyl Groups onto Nano-sized Silica Surface and $\mathrm{Mo}(\mathrm{CO})_{6}$

Into a polymerization tube, $0.20 \mathrm{~g}$ of silica having trichloroacetyl groups, $0.01 \mathrm{~g}$ of $\mathrm{Mo}(\mathrm{CO})_{6}, 0.50 \mathrm{~g}$ of $\mathrm{St}_{-} \mathrm{SO}_{3}{ }^{-} \mathrm{Na}^{+}$and $10.0 \mathrm{~mL}$ of DMSO were charged. The mixture was frozen in a liquid nitrogen bath, degassed with a vacuum pump, and then thawed. After this operation was repeated three times, the tube was sealed under high vacuum. The sealed tube was heated at $70^{\circ} \mathrm{C}$ with stirring. After the graft polymerization, the content of the tube was poured into a large excess of methanol. The precipitate thus obtained was filtered and dried in vacuo.

\footnotetext{
Introduction of Alkyl Phosphonium Salt to Grafted Chains on Nano-sized Silica Surface

Into a three-necked flask that contained $1.0 \mathrm{~g}$ of poly $\left(\mathrm{St}_{-} \mathrm{SO}_{3}{ }^{-} \mathrm{Na}^{+}\right)$-grafted silica and $50 \mathrm{~mL}$ of pure water, aqueous solution of $\mathrm{Bu}_{3} \mathrm{RP}^{+} \mathrm{Cl}^{-}(5.24 \mathrm{~mL}$ of $\mathrm{Bu}_{3} \mathrm{RP}^{+} \mathrm{Cl}^{-}$was dissolved in $12.3 \mathrm{~mL}$ of pure water)
}

was added dropwise under sitting with a magnetic stirrer and reacted at $30^{\circ} \mathrm{C}$ for $1.5 \mathrm{~h}$. After the reaction, the reaction mixture was centrifuged and precipitated silica was dispersed in pure water. The procedures were repeated until no more $\mathrm{Bu}_{3} \mathrm{RP}^{+} \mathrm{Cl}^{-}$could be detected in supernatant solution and dried in vacuo. The amount of $\mathrm{SO}_{3}{ }^{-} \mathrm{P}^{+} \mathrm{Bu}_{3} \mathrm{R}$ was determined from weight increment of silica after the treatment with $\mathrm{Bu}_{3} \mathrm{RP}^{+} \mathrm{Cl}^{-}$. The treated silica was abbreviated as Silica-poly $\left(\mathrm{SO}_{3}{ }^{-} \mathrm{P}^{+} \mathrm{Bu}_{3} \mathrm{R}\right)$.

\section{Determination of Percentage of Grafting}

The product was dispersed in DMSO and centrifuged. The supernatant solution was removed and silica precipitated was dispersed in DMSO. The procedures were repeated until no more ungrafted polymer could be detected in supernatant solution and dried in vacuo. The percentage of poly $\left(\mathrm{St}_{-} \mathrm{SO}_{3}{ }^{-} \mathrm{Na}^{+}\right)$ grafting (percentage of grafted polymer to silica) was calculated by the following equation:

$$
\text { Grafting }(\%)=(D / B) \times 100,
$$

where $D$ is poly $\left(\mathrm{St}_{-} \mathrm{SO}_{3}{ }^{-} \mathrm{Na}^{+}\right)$grafted onto silica surface and $B$ is silica charged. The amount of poly(St$\mathrm{SO}_{3}{ }^{-} \mathrm{Na}^{+}$) grafted onto silica surface is determined by weight loss, when poly $\left(\mathrm{St}_{-} \mathrm{SO}_{3}{ }^{-} \mathrm{Na}^{+}\right)$-grafted silica was heated at $800^{\circ} \mathrm{C}$ by use of a thermal analyzer (Shimadzu Manufacturing Co., Ltd., TGA-50).

Preparation of Silicone Rubber Filled with Antibacterial Polymer-grafted Silica

Poly $\left(\mathrm{SO}_{3}{ }^{-} \mathrm{P}^{+} \mathrm{Bu}_{3} \mathrm{R}\right)$-grafted silica was mixed with silicone and curing agent using a hybrid defoaming mixer (Thinky Co. Japan, AR-250) at room temperature. The mixture was cured at $120^{\circ} \mathrm{C}$ for $2 \mathrm{~h}$.

\section{Contact Angle of Silicone Rubber Filled with Poly- $\left(\mathrm{SO}_{3}{ }^{-} \mathrm{P}^{+} \mathrm{Bu}_{3} \mathrm{R}\right)$-grafted Silica}

Contact angle of water on silicone rubber filled with silica was determined by using a Contact Angle Meter. The determination of contact angle was carried out at different 10 points and the measured value was averaged.

Evaluation of Antibacterial Activity of Silicone Rubber Filled with the Antibacterial Polymer-grafted Silica

The evaluation of surface antibacterial activity of silicone rubber filled with poly $\left(\mathrm{SO}_{3}{ }^{-} \mathrm{P}^{+} \mathrm{Bu}_{3} \mathrm{R}\right)$-grafted silica was carried out by Japan Spinners Inspecting Foundation according to the method of Japanese Industrial Standards (JIS Z 2801). ${ }^{18}$ A typical example is as follows: Culture contains c.a. $2.5-10 \times 10^{5}$ cells $/ \mathrm{mL}$ was prepared by ordinary method and used for antibacterial test. 
The test piece $(40 \mathrm{~mm} \times 40 \mathrm{~mm} \times 2 \mathrm{~mm})$ was wiped lightly with absorbent cotton immersed in ethanol 3 times and dried completely and placed in a sterilized Petri dish making the test surface up. The above test inoculum was instilled with a pipet onto each test piece in the Petri dish: the number of bacteria cells inoculated was $2.0 \times 10^{5}-4.0 \times 10^{5}$ per test piece. The instilled test inoculum was covered with a film and the film was pressed so that the test inoculum spreads over the film. The Petri dishes containing the test piece inoculated with the test inoculum ( 3 untreated test pieces and 3 test pieces) were incubated at $35^{\circ} \mathrm{C}$ and a relative humidity of $90 \%$ for $24 \mathrm{~h}$. After the incubation, the test piece and the covering film were placed in a sterilized stomacher pouch using sterilized tweezers with caution so that the test inoculum does not spill. Then $10 \mathrm{~mL}$ of SCDLP broth with a pipet and massage the test piece and the covering film sufficiently with hands for the microbial test to wash out the test bacteria.

Exactly $1.0 \mathrm{~mL}$ of the washings was added into a test tube containing $9.0 \mathrm{~mL}$ of phosphate buffered physiological saline. Then $1.0 \mathrm{~mL}$ of the mixture in the test tube was added into another test tube containing $9.0 \mathrm{~mL}$ of phosphate buffered physiological saline. By repeating the procedures, 10-fold serial dilution was prepared. From these dilutions, the surviving bacteria were countered by the spread plate method. After inoculation, the plates were incubated at $35^{\circ} \mathrm{C}$. After $48 \mathrm{~h}$, the colonies were countered. The counting was carried out in triplicate every times.

An antibacterial activity was estimated by the decrease ratio of bacteria determined by the following equation:

$$
\mathrm{R}=[(E-F) / E] \times 100 .
$$

where $E$ is average of the number of initial cells of bacteria and $F$ is average of the number of viable cells of bacteria on the test piece.

\section{RESULTS AND DISCUSSION}

\section{Grafting of Poly $\left(\mathrm{St}_{-} \mathrm{SO}_{3}{ }^{-} \mathrm{Na}^{+}\right)$onto Nano-sized Silica Surface}

The grafting of poly $\left(\mathrm{St}_{-} \mathrm{SO}_{3}{ }^{-} \mathrm{Na}^{+}\right)$onto nano-sized silica surface by the polymerization of $\mathrm{St}_{-} \mathrm{SO}_{3}{ }^{-} \mathrm{Na}^{+}$ initiated by azo groups introduced onto the surface was investigated. Figure 2 shows relationship between poly $\left(\mathrm{St}_{-} \mathrm{SO}_{3}{ }^{-} \mathrm{Na}^{+}\right)$grafting and reaction time. No polymerization of poly $\left(\mathrm{St}_{-} \mathrm{SO}_{3}{ }^{-} \mathrm{Na}^{+}\right)$was initiated by untreated silica and no grafting of poly $\left(\mathrm{St}_{-} \mathrm{SO}_{3}{ }^{-} \mathrm{Na}^{+}\right)$ onto the surface proceeded. On the contrary, it was found that graft polymerization of St- $\mathrm{SO}_{3}{ }^{-} \mathrm{Na}^{+}$was successfully initiated by azo groups to give poly(St$\left.\mathrm{SO}_{3}{ }^{-} \mathrm{Na}^{+}\right)$-grafted silica. The grafting of poly(St-

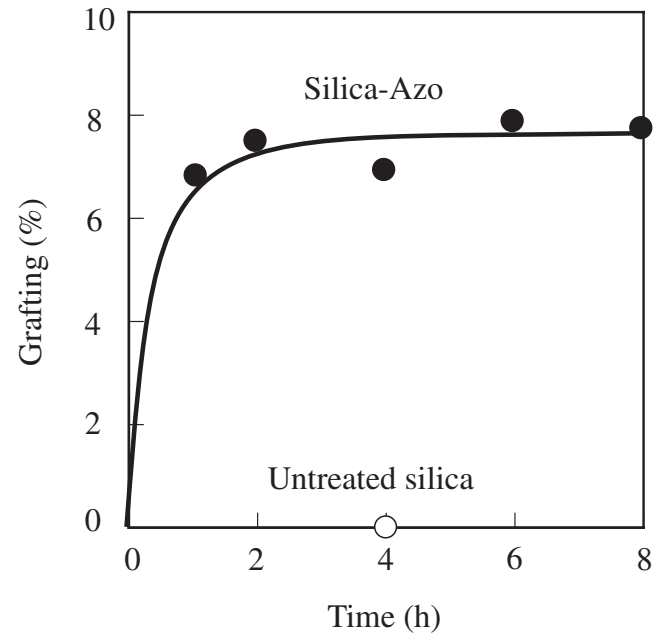

Figure 2. Grafting of poly $\left(\mathrm{St}_{-} \mathrm{SO}_{3}{ }^{-} \mathrm{Na}^{+}\right)$onto nano-sized silica surface by the polymerization of $\mathrm{St}_{-} \mathrm{SO}_{3}{ }^{-} \mathrm{Na}^{+}$initiated by azo groups introduced onto the surface. Silica-Azo, $0.20 \mathrm{~g}$; St$\mathrm{SO}_{3}{ }^{-} \mathrm{Na}^{+}, 0.50 \mathrm{~g}$; DMSO, $10.0 \mathrm{~mL} ; 70^{\circ} \mathrm{C}$.

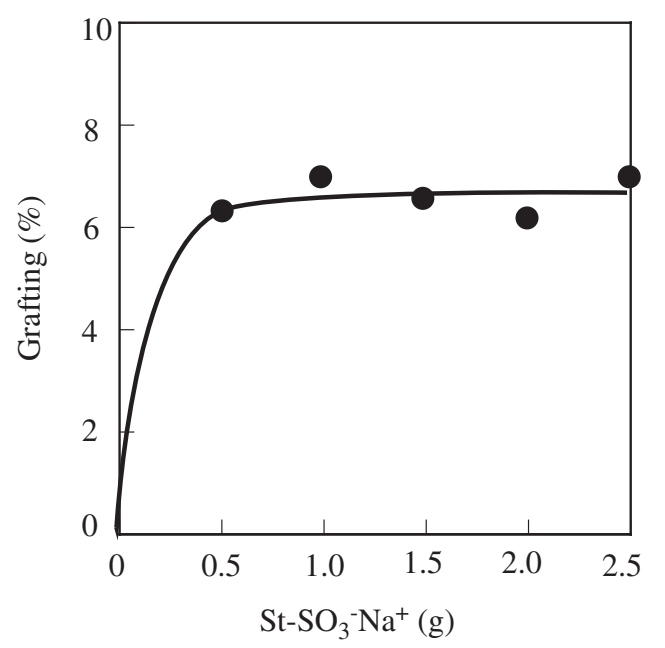

Figure 3. Effect of $\mathrm{St}_{-} \mathrm{SO}_{3}{ }^{-} \mathrm{Na}^{+}$concentration on the grafting of poly $\left(\mathrm{St}_{-} \mathrm{SO}_{3}{ }^{-} \mathrm{Na}^{+}\right)$onto nano-sized silica surface in the polymerization initiated by azo groups introduced onto the surface. Silica-Azo, $0.20 \mathrm{~g}$; DMSO, $10.0 \mathrm{~mL} ; 70^{\circ} \mathrm{C}, 1 \mathrm{~h}$.

$\mathrm{SO}_{3}{ }^{-} \mathrm{Na}^{+}$) onto the surface increased with progress of the polymerization, and no longer increased after $2 \mathrm{~h}$. This may be due to the fact that grafted polymer chains on the silica block the azo groups on the surface.

Figure 3 shows the effect of monomer charged on the grafting of poly $\left(\mathrm{St}_{-} \mathrm{SO}_{3}{ }^{-} \mathrm{Na}^{+}\right)$onto silica surface. The grafting hardly increased even if the concentration of monomer increased.

We have pointed out that the effective grafting of polymers onto silica surface can be achieved by use of the initiating system consisting of trichloroacetyl groups on the surface and $\mathrm{Mo}(\mathrm{CO})_{6}$ Therefore, the polymerization of $\mathrm{St}_{-} \mathrm{SO}_{3}{ }^{-} \mathrm{Na}^{+}$initiated by the system 


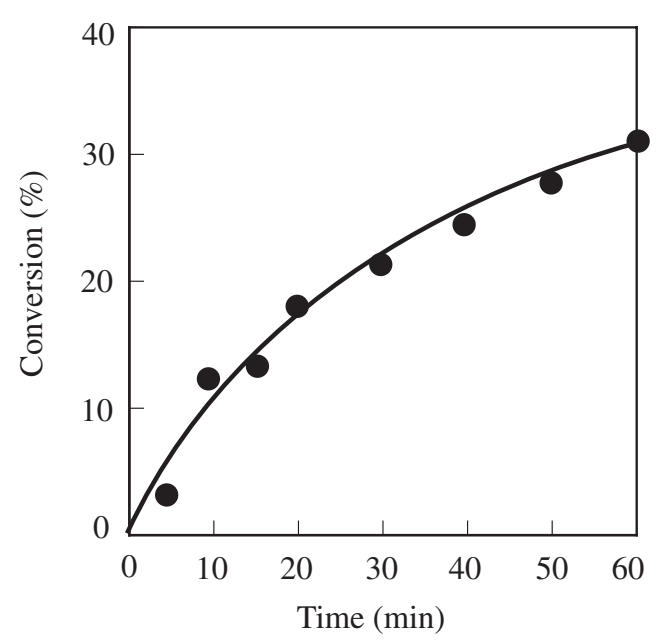

Figure 4. Graft polymerization of $\mathrm{St}_{-} \mathrm{SO}_{3}{ }^{-} \mathrm{Na}^{+}$onto nanosized silica surface by the polymerization of $\mathrm{St}_{-} \mathrm{SO}_{3}{ }^{-} \mathrm{Na}^{+}$initiated by the system consisting of Silica- $\mathrm{COCCl}_{3}$ and $\mathrm{Mo}(\mathrm{CO})_{6}$. Silica$\mathrm{COCCl}_{3}, 0.20 \mathrm{~g} ; \mathrm{St}_{-} \mathrm{SO}_{3}{ }^{-} \mathrm{Na}^{+}, 0.50 \mathrm{~g} ; \mathrm{Mo}(\mathrm{CO})_{6}, 0.01 \mathrm{~g}$; DMSO, $10.0 \mathrm{~mL} ; 70^{\circ} \mathrm{C}$.

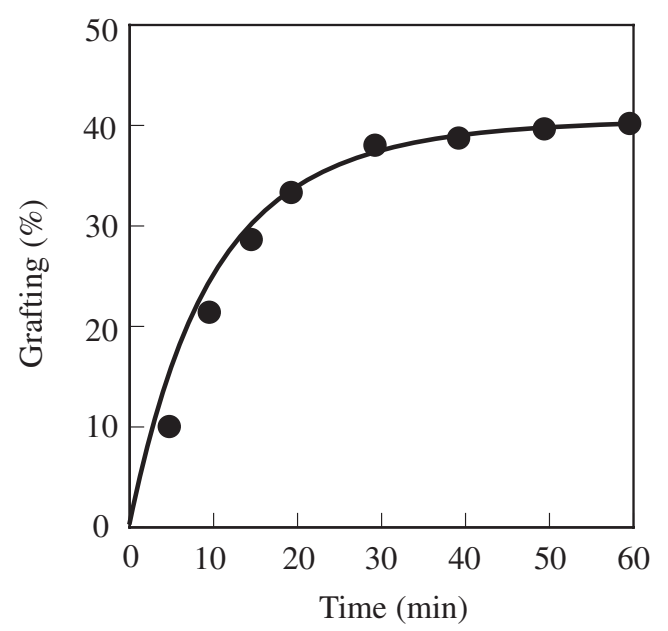

Figure 5. Grafting of poly $\left(\mathrm{St}_{-} \mathrm{SO}_{3}{ }^{-} \mathrm{Na}^{+}\right)$onto nano-sized silica surface during the polymerization shown in Figure 4. The reaction conditions are shown in Figure 4.

consisting of Silica-COCCl${ }_{3}$ and $\mathrm{Mo}(\mathrm{CO})_{6}$ was also investigated. The results are shown in Figure 4.

The graft polymerization of $\mathrm{St}-\mathrm{SO}_{3} \mathrm{Na}$ was also successfully initiated by the system to give poly(St$\mathrm{SO}_{3}{ }^{-} \mathrm{Na}^{+}$)-grafted silica. The grafting of poly(St$\mathrm{SO}_{3}{ }^{-} \mathrm{Na}^{+}$) onto the surface increased with progress of the polymerization as shown in Figure 5. This suggests that poly $\left(\mathrm{St}_{-} \mathrm{SO}_{3}{ }^{-} \mathrm{Na}^{+}\right)$is propagated from the surface radicals formed by the interaction of surface trichloroacetyl groups with $\mathrm{Mo}(\mathrm{CO})_{6}$.

It is interesting to note that poly $\left(\mathrm{St}_{-} \mathrm{SO}_{3}{ }^{-} \mathrm{Na}^{+}\right)$ grafting onto silica surface in Silica- $\mathrm{COCCl}_{3} /$ $\mathrm{Mo}(\mathrm{CO})_{6}$ system was much higher than that in the polymerization initiated by Silica-azo. This reason may be explained as follows: Surface azo groups on silica produce both surface radicals and primary (fragment) radicals. The surface radicals initiate the graft polymerization of $\mathrm{St}_{-} \mathrm{SO}_{3}{ }^{-} \mathrm{Na}^{+}$, but fragment radical produces ungrafted polymer. In the middle and last stage of the polymerization, the formation of ungrafted polymer preferentially proceeds because of blocking of surface radicals by grafted polymer chains on the surface. ${ }^{5,6}$ On the contrary, in the $\mathrm{COCCl}_{3} /$ $\mathrm{Mo}(\mathrm{CO})_{6}$ system, propagation of grafted chain from the surface effectively achieved because of the absence of fragment radicals, which produce ungrafted polymer. ${ }^{7,8}$

To isolate of polySt- $\mathrm{SO}_{3}{ }^{-} \mathrm{Na}^{+}$grafted onto the silica surface during the above graft polymerization, polySt- $\mathrm{SO}_{3}{ }^{-} \mathrm{Na}^{+}$-grafted silica was treated with alkali solution. But polySt- $\mathrm{SO}_{3}{ }^{-} \mathrm{Na}^{+}$was failed to isolate from the resulting alkali solution. Therefore, the determination of molecular weight of polySt- $\mathrm{SO}_{3}{ }^{-} \mathrm{Na}^{+}$ grafted onto the silica surface could not be achieved.

The molecular weight of polySt- $\mathrm{SO}_{3}{ }^{-} \mathrm{Na}^{+}$grafted onto the silica surface was presumed to be $10^{4}-10^{5}$ from that of polystyrene obtained from the graft polymerization of styrene onto silica surface initiated by the above initiating system. ${ }^{7}$

\section{Introduction of Alkyl Phosphonium Salt to Grafted Chains on Nano-sized Silica Surface}

Ikeda et al. have reported that polymeric phosphonium salts shows strong antibacterial activity to Staphylococcus aureus and an Escherichia coli. ${ }^{17}$ Therefore, the introduction of phosphonium salt groups to grafted chains on silica surface was investigated.

Poly $\left(\mathrm{St}_{-} \mathrm{SO}_{3}{ }^{-} \mathrm{Na}^{+}\right)$-grafted silica was treated with $\mathrm{Bu}_{3} \mathrm{RP}^{+} \mathrm{Cl}$ to convert the sulfonium groups to alkyl phosphonium salt $\left(\mathrm{SO}_{3}{ }^{-} \mathrm{P}^{+} \mathrm{Bu}_{3} \mathrm{R}\right)$ groups. Figure 6 shows infrared spectra of (A) poly $\left(\mathrm{St}_{-} \mathrm{SO}_{3}{ }^{-} \mathrm{Na}^{+}\right)$grafted silica and (B) poly $\left(\mathrm{St}_{-} \mathrm{SO}_{3}{ }^{-} \mathrm{Na}^{+}\right)$-grafted silica treated with $\mathrm{Bu}_{3} \mathrm{RP}^{+} \mathrm{Cl}$. Infrared spectra of the latter (B) show new adsorptions at 1456 and $2927 \mathrm{~cm}^{-1}$, which are characteristic of phosphonium group and alkyl group, respectively. Therefore, it is concluded that the sulfonium groups of poly $\left(\mathrm{St}_{-} \mathrm{SO}_{3}{ }^{-} \mathrm{Na}^{+}\right)$grafted silica was successfully converter to poly(St$\mathrm{SO}_{3}{ }^{-} \mathrm{P}^{+} \mathrm{Bu}_{3} \mathrm{R}$ )-grafted silica by the treatment with $\mathrm{Bu}_{3} \mathrm{RP}^{+} \mathrm{Cl}$ as shown in Scheme 2 .

Figure 7 shows the percentage of grafted poly$\left(\mathrm{St}_{-} \mathrm{SO}_{3}{ }^{-} \mathrm{Na}^{+}\right.$) chain on silica surface converted to poly $\left(\mathrm{St}_{-} \mathrm{SO}_{3}{ }^{-} \mathrm{P}^{+} \mathrm{Bu}_{3} \mathrm{R}\right)$. The percentage of $\mathrm{SO}_{3}{ }^{-} \mathrm{Na}^{+}$ groups reacted with $\mathrm{Bu}_{3} \mathrm{RP}^{+} \mathrm{Cl}$ decreased with increasing polymer grafting. This may be due to the increase of steric hindrance with increasing poly(St$\mathrm{SO}_{3}{ }^{-} \mathrm{Na}^{+}$) grafting.

The poly $\left(\mathrm{St}_{-} \mathrm{SO}_{3}{ }^{-} \mathrm{P}^{+} \mathrm{Bu}_{3} \mathrm{R}\right)$-grafted silica gave a stable dispersion in DMSO. In addition, the silica 


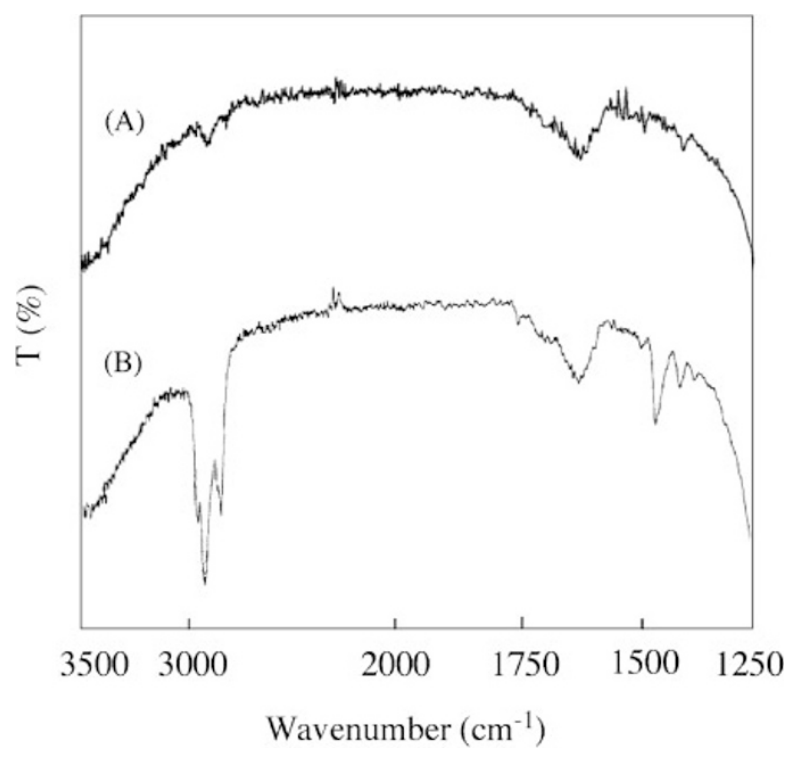

Figure 6. FT-IR spectra of (A) poly $\left(\mathrm{St}_{-} \mathrm{SO}_{3}{ }^{-} \mathrm{Na}^{+}\right)$-grafted silica and (B) poly $\left(\mathrm{St}_{-} \mathrm{SO}_{3}{ }^{-} \mathrm{Na}^{+}\right)$-grafted silica treated with $\mathrm{Bu}_{3} \mathrm{RP}^{+} \mathrm{Cl}$.

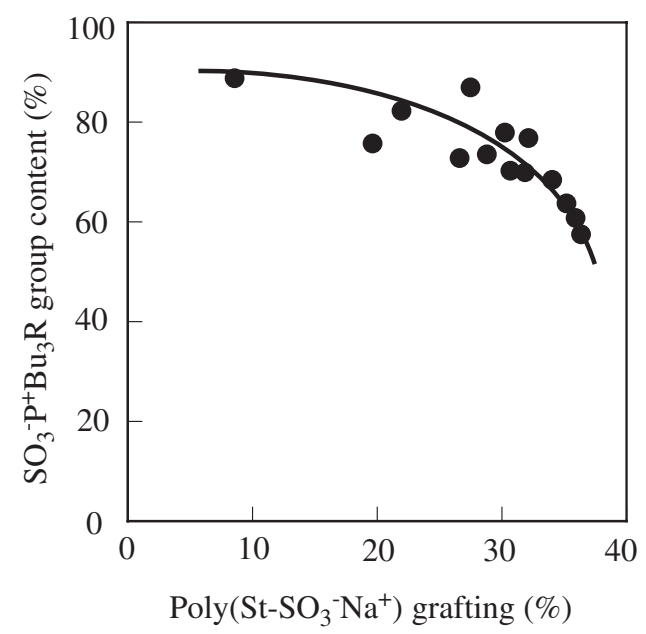

Figure 7. The percentage of grafted poly $\left(\mathrm{St}_{-} \mathrm{SO}_{3}{ }^{-} \mathrm{Na}^{+}\right)$chain on silica surface converted to poly $\left(\mathrm{St}_{-} \mathrm{SO}_{3}{ }^{-} \mathrm{P}^{+} \mathrm{Bu}_{3} \mathrm{R}\right)$.

easily and uniformly dispersed in poly(dimethylsiloxane).

Contact Angle of Silicone Rubber Filled with Poly(St$\mathrm{SO}_{3}{ }^{-} \mathrm{P}^{+} \mathrm{Bu} \mathrm{u}_{3} \mathrm{R}$ )-grafted Silica

Table I shows contact angel of water to silicone rubber filled with poly $\left(\mathrm{St}_{-} \mathrm{SO}_{3}{ }^{-} \mathrm{P}^{+} \mathrm{Bu}_{3} \mathrm{R}\right)$-grafted silica. As shown in Table I, the contact angel of water to silicone rubber filled with untreated silica decreased with increasing content of silica, because untreated silica shows hydrophilic nature. On the contrary, the contact angel of water to silicone rubber filled with poly(St$\mathrm{SO}_{3}{ }^{-} \mathrm{P}^{+} \mathrm{Bu}_{3} \mathrm{R}$ )-grafted silica increased with increasing the content of poly $\left(\mathrm{St}_{-} \mathrm{SO}_{3}{ }^{-} \mathrm{P}^{+} \mathrm{Bu}_{3} \mathrm{R}\right)$-grafted silica. This may be due to the hydrophobic alkyl chain of poly $\left(\mathrm{St}_{-} \mathrm{SO}_{3}{ }^{-} \mathrm{P}^{+} \mathrm{Bu}_{3} \mathrm{R}\right)$ grafted on silica surface.
Table I. Contact angle of silicone rubber filled with $\mathrm{Poly}\left(\mathrm{StSO}_{3}{ }^{-} \mathrm{P}^{+} \mathrm{Bu}_{3} \mathrm{R}\right)$-grafted silica

\begin{tabular}{|c|c|c|}
\hline Silica & $\begin{array}{c}\text { Content } \\
(\%)\end{array}$ & $\begin{array}{c}\text { Contact Angle } \\
\left({ }^{\circ}\right)\end{array}$ \\
\hline None & & 103.7 \\
\hline Untreated & 1 & 100.7 \\
\hline Untreated & 5 & 99.8 \\
\hline Untreated & 10 & 96.9 \\
\hline Poly $\left(\mathrm{St}_{-} \mathrm{SO}_{3}{ }^{-} \mathrm{P}^{+} \mathrm{Bu}_{3} \mathrm{R}\right)$-grafted & 1 & 106.8 \\
\hline Poly $\left(\mathrm{St}_{-} \mathrm{SO}_{3}{ }^{-} \mathrm{P}^{+} \mathrm{Bu}_{3} \mathrm{R}\right)$-grafted & 5 & 111.2 \\
\hline Poly $\left(\mathrm{St}_{-} \mathrm{SO}_{3}{ }^{-} \mathrm{P}^{+} \mathrm{Bu}_{3} \mathrm{R}\right)$-grafted & 10 & 117.8 \\
\hline
\end{tabular}

Silicone rubber, $10.0 \mathrm{~g}$; poly $\left(\mathrm{St}_{-} \mathrm{SO}_{3}{ }^{-} \mathrm{P}^{+} \mathrm{Bu}_{3} \mathrm{R}\right)$-grafted silica $($ Overall grafting $=53.8 \%)$.

Table II. Antibacterial activity of silicone rubber filled with Poly $\left(\mathrm{St}_{-} \mathrm{SO}_{3}{ }^{-} \mathrm{P}^{+} \mathrm{Bu}_{3} \mathrm{R}\right)$-grafted silica to Staphylococcus aureus ${ }^{\mathrm{a}}$

\begin{tabular}{lccc}
\hline \multicolumn{1}{c}{ Silica } & $\begin{array}{c}\text { Content } \\
(\%)\end{array}$ & $\begin{array}{c}\text { Living cells } \\
\left(\text { cells } / \mathrm{cm}^{2}\right)\end{array}$ & $\begin{array}{c}\text { Decrease } \\
\text { ratio }(\%)\end{array}$ \\
\hline Untreated silica & 10 & $4.1 \times 10^{5}$ & $-105^{\mathrm{b}}$ \\
Silica-Poly $\left(\mathrm{St}_{-} \mathrm{SO}_{3}{ }^{-} \mathrm{P}^{+} \mathrm{Bu}_{3} \mathrm{R}\right)$ & 1 & $<10$ & 100 \\
Silica-Poly $\left(\mathrm{St}_{-} \mathrm{SO}_{3}{ }^{-} \mathrm{P}^{+} \mathrm{Bu}_{3} \mathrm{R}\right)$ & 5 & $<10$ & 100 \\
Silica-Poly $\left(\mathrm{St}_{-} \mathrm{SO}_{3}{ }^{-} \mathrm{P}^{+} \mathrm{Bu}_{3} \mathrm{R}\right)$ & 10 & $<10$ & 100 \\
\hline
\end{tabular}

${ }^{\mathrm{a} C e l l s}$ inoculated, $2.0 \times 10^{5}$ per test piece $(40 \mathrm{~mm} \times 40 \mathrm{~mm} \times$ $2 \mathrm{~mm}) .{ }^{\mathrm{b}}$ Cells propagated.

Table III. Antibacterial activity of silicone rubber filled with Poly $\left(\mathrm{St}_{-} \mathrm{SO}_{3}{ }^{-} \mathrm{P}^{+} \mathrm{Bu}_{3} \mathrm{R}\right)$-grafted silica to Escherichia Coli ${ }^{\text {a }}$

\begin{tabular}{lccc}
\hline \multicolumn{1}{c}{ Silica } & $\begin{array}{c}\text { Content } \\
(\%)\end{array}$ & $\begin{array}{c}\text { Living cells } \\
\left(\text { cells } / \mathrm{cm}^{2}\right)\end{array}$ & $\begin{array}{c}\text { Decrease } \\
\text { ratio (\%) }\end{array}$ \\
\hline Untreated silica & 10 & $1.9 \times 10^{6}$ & $-493^{\mathrm{b}}$ \\
Silica-Poly $\left(\mathrm{St}_{-} \mathrm{SO}_{3}{ }^{-} \mathrm{P}^{+} \mathrm{Bu}_{3} \mathrm{R}\right)$ & 1 & $7.9 \times 10^{5}$ & $-146^{\mathrm{b}}$ \\
Silica-Poly $\left(\mathrm{St}_{-} \mathrm{SO}_{3}{ }^{-} \mathrm{P}^{+} \mathrm{Bu}_{3} \mathrm{R}\right)$ & 5 & $<10$ & 100 \\
Silica-Poly $\left(\mathrm{St}_{-} \mathrm{SO}_{3}{ }^{-} \mathrm{P}^{+} \mathrm{Bu}_{3} \mathrm{R}\right)$ & 10 & $<10$ & 100 \\
\hline
\end{tabular}

${ }^{\mathrm{a}}$ Cells inoculated, $3.2 \times 10^{5}$ cells per test piece $(40 \mathrm{~mm} \times$ $40 \mathrm{~mm} \times 2 \mathrm{~mm}) .{ }^{\mathrm{b}}$ Cells propagated.

Evaluation of Antibacterial Nature of Silicone Rubber Filled with the Antibacterial Polymer-grafted Silica

The composite of silicone rubber filled with poly( $\mathrm{St}-\mathrm{SO}_{3}{ }^{-} \mathrm{P}^{+} \mathrm{Bu}_{3} \mathrm{R}$ )-grafted silica was prepared and the surface antibacterial activity was investigated. The content of poly $\left(\mathrm{St}_{-} \mathrm{SO}_{3}{ }^{-} \mathrm{P}^{+} \mathrm{Bu}_{3} \mathrm{R}\right)$-grafted silica was 1.0, 5.0 and $10.0 \%$.

Tables II and III show antibacterial activity of the surface of silicone rubber filled with silica to Staphylococcus aureus and Escherichia coli. As shown in Table II, It was found that cells of Staphylococcus aureus increased from $2.0 \times 10^{5}$ cells $/ \mathrm{cm}^{2}$ to $4.1 \times$ $10^{5}$ cells $/ \mathrm{cm}^{2}$ on silicone rubber filled with untreated silica. On the contrary, the propagation of the cell almost completely inhibited on silicone rubber filled with $1 \%-10 \%$ of poly $\left(\mathrm{St}_{-} \mathrm{SO}_{3}{ }^{-} \mathrm{P}^{+} \mathrm{Bu}_{3} \mathrm{R}\right)$-grafted silica: the antibacterial activity was $100 \%$.

As shown in Table III, the antibacterial activity of those filled with $5 \%-10 \%$ of poly $\left(\mathrm{St}_{-} \mathrm{SO}_{3}{ }^{-} \mathrm{P}^{+} \mathrm{Bu}_{3} \mathrm{R}\right)$ - 


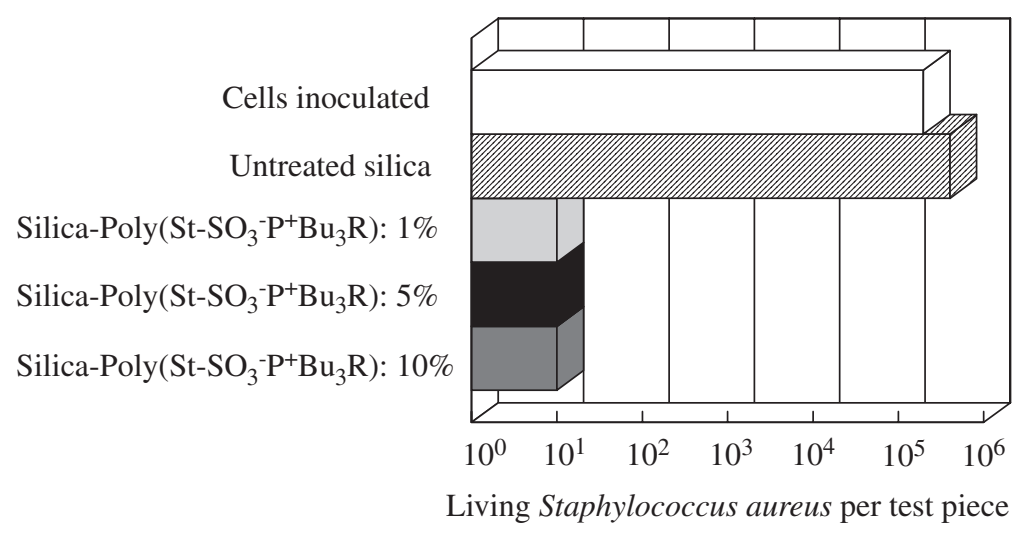

Figure 8. Antibacterial activity of silicone rubber surface filled with poly $\left(\mathrm{St}_{-} \mathrm{SO}_{3}{ }^{-} \mathrm{P}^{+} \mathrm{Bu}_{3} \mathrm{R}\right)$-grafted silica to Staphylococcus aureus. The number of bacteria cells inoculated was $2.0 \times 10^{5}$ per test piece $(40 \mathrm{~mm} \times 40 \mathrm{~mm} \times 2 \mathrm{~mm})$.

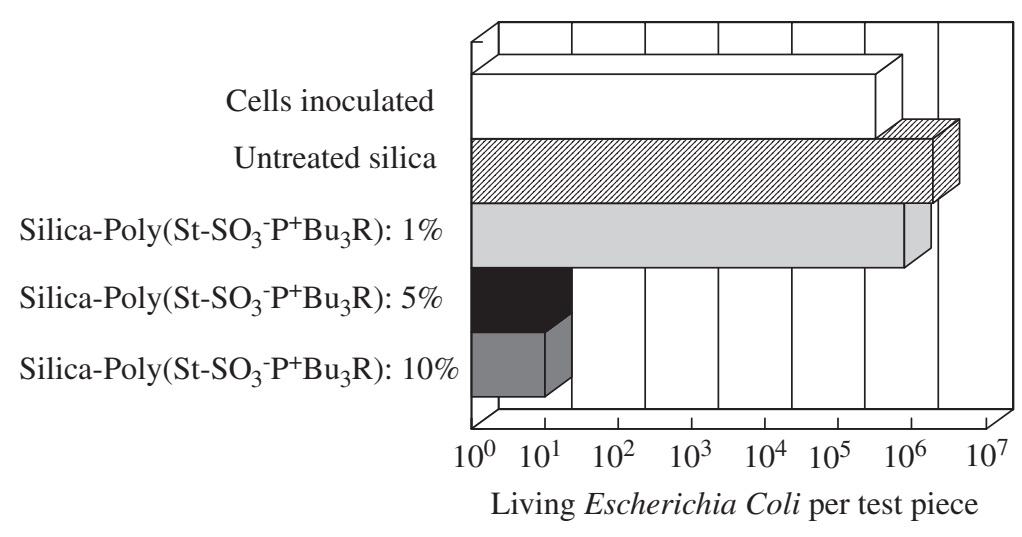

Figure 9. Antibacterial activity of silicone rubber surface filled with poly( $\left.\mathrm{St}_{-} \mathrm{SO}_{3}{ }^{-} \mathrm{P}^{+} \mathrm{Bu}_{3} \mathrm{R}\right)$-grafted silica to Escherichia coli. The number of bacteria cells inoculated was $3.2 \times 10^{5}$ per test piece $(40 \mathrm{~mm} \times 40 \mathrm{~mm} \times 2 \mathrm{~mm})$.

grafted silica against to Escherichia coli was $100 \%$. However, Escherichia coli propagated on the surface of silicone rubber filled with $1 \%$ of poly(St$\mathrm{SO}_{3}{ }^{-} \mathrm{P}^{+} \mathrm{Bu}_{3} \mathrm{R}$ )-grafted silica. This may be due to the fact that the propagation rate of Escherichia coli was larger than those Staphylococcus aureus in the cultivation conditions.

Figures 8 and 9 also show the antibacterial activity of the silicone rubber against Staphylococcus aureus and an Escherichia coli, respectively.

These results indicate that we can readily prepare composites having antibacterial surface from the antibacterial polymer-grafted silica. The methods for the preparation of antibacterial surface have several advantages, no damage of the bulk polymers and simple processes for the preparation. Therefore, the composites from antibacterial polymer-grafted silica have potential use as sanitary goods, toilet seats, medical polymer tubes, and paints.

\section{CONCLUSIONS}

1. Poly $\left(\mathrm{St}_{-} \mathrm{SO}_{3}{ }^{-} \mathrm{Na}^{+}\right)$was successfully achieved by the radical polymerization of $\mathrm{St}_{-} \mathrm{SO}_{3}{ }^{-} \mathrm{Na}^{+}$initi- ated by the system consisting of trichloroacetyl groups on the silica surface and $\mathrm{Mo}(\mathrm{CO})_{6}$.

2. Sodium sulfonate groups of poly $\left(\mathrm{St}_{-} \mathrm{SO}_{3}{ }^{-} \mathrm{Na}^{+}\right)$grafted silica were successfully converted to $\mathrm{SO}_{3}{ }^{-} \mathrm{P}^{+} \mathrm{Bu}_{3} \mathrm{R}$ groups by the treatment with $\mathrm{Bu}_{3} \mathrm{RP}^{+} \mathrm{Cl}$.

3. Silicone rubber filled with the poly $\left(\mathrm{St}_{-} \mathrm{SO}_{3}{ }^{-} \mathrm{P}^{+}-\right.$ $\mathrm{Bu}_{3} \mathrm{R}$ )-grafted-grafted silica shows strong antibacterial activity. The silicone rubber surface has an ability to inhibit the reproduction of Escherichia coli and Staphylococcus aureus.

\section{REFERENCES}

1. J. P. Blits and C. B. Little, in "Fundamental and Applied Aspects of Chemically Modified Surfaces," N. Tsubokawa, Ed., The Royal Soc. Chem., CRC Press, London, 1999, p 36.

2. N. Tsubokawa, Bull. Chem. Soc. Jpn., 75, 2115 (2002).

3. N. Tsubokawa, Polym. J., 37, 637 (2005).

4. R. Yokoyama, S. Suzuki, K. Shirai, T. Yamauchi, N. Tsubokawa, and M. Tsuchimochi, Eur. Polym. J., submitted for publication.

5. N. Tsubokawa, A. Kogure, K. Maruyama, Y. Sone, and M. Shimomura, Polym. J., 22, 827 (1990).

6. K. Fujiki, N. Tsubokawa, and Y. Sone, Polym. J., 22, 661 
(1990).

7. Y. Shirai and N. Tsubokawa, React. Funct. Polym., 32, 153 (1997).

8. G. Wei, S. Saitoh, H. Saitoh, K. Fujiki, T. Yamauchi, and N. Tsubokawa, Polymer, 45, 8723 (2004).

9. K. Ohno, K. Koh, Y. Tsuji, and T. Fukuda, Macromolecules, 35, 8989 (2002).

10. K. Ohno, K. Koh, Y. Tsuji, and T. Fukuda, Angew. Chem., Int. Ed., 42, 2751 (2003).

11. K. Yoshinaga and M. Teramoto, Bull. Chem. Soc. Jpn., 69, 2667 (1996).

12. K. Yoshinaga, J. Shimada, H. Nishida, and M. Komatsu, J. Colloid Interface Sci., 214, 180 (1999).

13. Y. Kaneko, Y. Imai, K. Shirai, T. Yamauchi, and N. Tsubokawa, J. Colloid Interface Sci., submitted for publication.

14. Y. Kagawa, N. Doi, T. Tawaratani, and I. Shibasaki, J. Antibact. Antifung. Agents, 11, 263 (1983).
15. T. Ikeda, H. Yamaguchi, and S. Tazuke, J. Bioact. Compat. Polym., 1, 301 (1986).

16. a) A. Kanazawa, T. Ikeda, and T. Endo, J. Polym. Sci., Part A: Polym. Chem., 31, 335 (1993).

b) A. Kanazawa, T. Ikeda, and T. Endo, J. Polym. Sci., Part A: Polym. Chem., 31, 1441 (1993).

c) A. Kanazawa, T. Ikeda, and T. Endo, J. Polym. Sci., Part A: Polym. Chem., 31, 1467 (1993).

d) A. Kanazawa, T. Ikeda, and T. Endo, J. Polym. Sci., Part A: Polym. Chem., 31, 2873 (1993).

e) A. Kanazawa, T. Ikeda, and T. Endo, J. Polym. Sci., Part A: Polym. Chem., 31, 3031 (1993).

17. A. Kanazawa, T. Ikeda, and T. Endo, J. Polym. Sci., Part A: Polym. Chem., 31, 3003 (1993).

18. Japanese Industrial Standards (JIS), Antimicrobial products: Test for antimicrobial activity and efficacy, JIS Z 2801 (2000). 